\begin{tabular}{l|l|l} 
Jurnal Eksplorasi Akuntansi & e-ISSN : 2656-3649 (Online) \\
Vol. 3, No 1, Februari 2021, Hal 1-11 & http://jea.ppj.unp.ac.id/index.php/jea
\end{tabular}

\title{
Pengaruh Pendapatan Asli Daerah, Dana Alokasi Umum dan Belanja Daerah terhadap Kinerja Keuangan Pemerintah Daerah Kabupaten/Kota di Provinsi Sumatera Barat
}

\author{
Berti Indah Sari' ${ }^{1}$, Halmawati ${ }^{2}$ \\ ${ }^{1,2}$ Jurusan Akuntansi Fakultas Ekonomi, Universitas Negeri Padang \\ *Korespondesi: bertiindahsari@gmail.com
}

\begin{abstract}
This study aims to examine the effect of local revenue, general allocation funds and regional spending on the financial performance of local governments. The sample used in this study were districts / cities of West Sumatra Province with 12 districts and 7 cities in West Sumatra. The data used in this study is the data on the realization of the District / City APBD in West Sumatra Province for the 2015-2018 fiscal year. This research uses descriptive statistical data analysis techniques, classical assumption test, multiple linear regression analysis, hypothesis testing and determination coefficient test. The results showed that the Regional Original Revenue, DAU and Regional Expenditures together had a significant positive effect on Regional Government Financial Performance. The test results are in accordance with the previous theory and hypothesis which states that PAD, DAU and Regional Expenditures have a significant positive effect on the financial performance of local governments.
\end{abstract}

Keywords: financial performance; general Allocation fund; locally-generated revenue; regional expenditure

How to cite (APA $6^{\text {th }}$ style)

Halmawati \& Sari, B.I (2020). Pengaruh Pendapatan Asli Daerah, Dana Alokasi Umum dan Belanja Daerah terhadap Kinerja Keuangan Pemerintah Daerah Kabupaten/Kota di Provinsi Sumatera Barat. Jurnal Eksplorasi Akuntansi. 3(1), 1-11.

\section{PENDAHULUAN}

Berdasarkan Undang-Undang Nomor 23 Tahun 2014 tentang pemerintahan daerah bahwa, otonomi daerah adalah hak, wewenang dan kewajiban daerah otonom untuk mengatur dan mengurus sendiri urusan pemerintahan dan kepentingan masyarakat setempat dalam sistem Negara Kesatuan Republik Indonesia. Sejak berlakunya Undang-Undang tersebut, pemerintah daerah telah diberi kewenangan yang lebih luas untuk menyelenggarakan segala urusan pemerintahan mulai dari perencanaan, pembangunan, pengendalian dan evaluasi. Oleh sebab itu, pemerintah daerah perlu mengembangkan segala potensi yang ada di daerah dalam rangka membangun dan mengembangkan daerahnya. Untuk memahami sejauh mana upaya yang dilakukan oleh pemerintah daerah dalam membangun daerahnya, kita perlu menilai sejauh mana kinerja pemerintah daerah dalam memajukan daerah dan mengelola keuangan daerahnya.

Menurut Peraturan Pemerintah Nomor 12 tahun 2019, kinerja adalah keluaran/hasil dari program/kegiatan yang akan atau telah dicapai sehubungan dengan penggunaan 
anggaran dengan kuantitas dan kualitas yang terukur. Berdasarkan PP 12 tahun 2019 kinerja keuangan daerah adalah program atau kegiatan yang telah dicapai pemerintah daerah sehubungan dengan penggunaan anggaran terhadap semua hak dan kewajiban daerah dalam rangka penyelenggaraan pemerintahan daerah. Menurut Peraturan Pemerintah Nomor 12 Tahun 2019 tentang Pengelolaan Keuangan Daerah, PAD bersumber dari pajak daerah, retribusi daerah, hasil pengelolaan kekayaan daerah yang dipisahkan dan lain-lain pendapatan asli daerah yang sah. PAD yang dihasilkan pemerintah daerah diharapkan dapat mendanai pelaksanaan otonomi daerahnya dengan menggali potensi daerah yang ada. Selain itu, PAD dapat mewujudkan kemandirian daerah sehingga pemerintah daerah tidak selalu bergantung pada pemerintah pusat.

PAD sendiri merupakan sumber utama pembiayaan dan pengeluaran daerah. Oleh karena itu, daerah harus dapat menggali sumber daya dan mengidentifikasi sumber daya yang dimilikinya untuk meningkatkan PAD. Semakin besar kontribusi PAD terhadap struktur APBD, maka akan semakin kecil pula ketergantungan daerah kepada pemerintah pusat (Abdullah, 2015). Selain PAD, penerimaan daerah juga berasal dari Dana Alokasi Umum (DAU). DAU adalah dana dalam bentuk dana perimbangan dari pemerintah pusat. Besarnya dana perimbangan akan menunjukkan bahwa, pemerintah daerah semakin bergantung kepada pemerintah pusat dalam memenuhi kebutuhan daerahnya (Julitawati, 2012). Dana Alokasi Umum (DAU) bersumber dari penerimaan APBN yang bertujuan untuk pemerataan kemampuan keuangan antar daerah dalam rangka pelaksanaan desentralisasi dan penyediaan dana untuk kebutuhan daerah. Kepala daerah menggunakan DAU berdasarkan prioritas dan kebutuhan daerah untuk peningkatan pelayanan kepada masyarakat dalam melaksanakan otonomi daerah. Faktanya, sebagian besar DAU difokuskan pada belanja pegawai yang menjadi hal krusial di daerah. Karena urgensi dari belanja tidak sesuai dengan kebutuhan, pembangunan serta tuntutan yang ada di masyarakat. Akibatnya, fungsi yang dijalankan pemerintah daerah tidak sesuai dengan kinerjanya.

Menurut Peraturan Pemerintah Republik Indonesia Nomor 12 Tahun 2019 belanja daerah terdiri dari; belanja operasi, belanja modal, belanja tidak terduga dan belanja transfer. Belanja daerah sebagaimana dimaksud dalam Permendagri Nomor 13 Tahun 2006, belanja daerah dipergunakan dalam rangka pelaksanaan urusan pemerintahan yang menjadi kewenangan provinsi atau kabupaten/kota yang terdiri dari urusan wajib dan urusan pilihan dan urusan yang penanganannya dalam bagian atau bidang tertentu yang dapat dilaksanakan bersama antara pemerintah dan pemerintah daerah atau antar pemerintah daerah yang ditetapkan berdasarkan peraturan perundang-undangan.

Dilihat dari total realisasi pendapatan tahun 2016 di seluruh daerah tingkat kabupaten/kota se-Sumatera Barat tercatat sebesar 18.812,96 miliar rupiah, meningkat 6,48 persen dibandingkan tahun 2015. Sebagian besar pendapatan kabupaten/kota bersumber dari dana perimbangan $15.407,12$ milyar rupiah (81,90 persen), diikuti lain-lain pendapatan daerah yang sah $1.722,61$ miliar rupiah $(9,16$ persen). Sementara, penerimaan daerah dari PAD masih sangat rendah, yaitu 1.683,23 miliar rupiah atau sekitar 8,95 persen dari total pendapatan. Penerimaan PAD seharusnya dapat menjadi sumber pendapatan utama di daerah tersebut, karena pendapatan ini digali dari potensi daerah dan daerah mempunyai kewenangan penuh dalam memanfaatkan PAD ini sesuai kebutuhan dan prioritas daerah. Berdasarkan hal tersebut, kinerja keuangan pemerintah menjadi sangat rendah karena rendahnya kontribusi dari PAD tersebut.

Umumnya pendapatan kabupaten/kota sebagian besar berasal dari dana perimbangan, terutama diperoleh dari dana alokasi umum. Hal tersebut menunjukkan bahwa, masih tingginya ketergantungan pemerintah daerah terhadap pemerintah pusat dan juga menunjukkan rendahnya tingkat kinerja keuangan pemerintah daerah. Sementara itu, pada sisi pengeluaran sebagian besar belanja pemerintah kabupaten/kota lebih banyak terserap 
untuk kebutuhan belanja tidak langsung dibandingkan untuk kebutuhan belanja langsung. Pada tahun 2016 pemerintah kabupaten/kota telah mengeluarkan dana sebesar 19.324,81 miliar rupiah untuk belanja daerah, dengan realisasi sebesar 55,38 persen untuk belanja tidak langsung dan 44,62 persen untuk belanja langsung. Pemanfaatan belanja langsung senilai 8.621,97 miliar rupiah sebagian besar dialokasikan untuk belanja modal sebesar 4.215,50 miliar rupiah (48,89 persen), dan untuk belanja barang dan jasa sebesar 3.832,41 miliar rupiah (44,45 persen). Belanja pegawai hanya sebesar 574,06 miliar rupiah (6,66 persen).

Belanja daerah kabupaten/kota di Sumatera Barat sebagian besar dimanfaatkan untuk belanja tidak langsung. Dimana berdasarkan Permendagri nomor 25 tahun 2009 belanja langsung diupayakan lebih besar dari belanja tidak langsung. Sementara data diatas menunjukkan bahwa belanja tidak langsung lebih besar dari belanja langsung. Hal tersebut menunjukkan masih rendahnya tingkat kinerja keuangan pemerintah daerah. Pada tahun 2018 data laporan realisasi anggaran yang diperoleh dari BPK RI menunjukkan bahwa, hampir seluruh daerah kabupaten/kota di provinsi Sumbar terjadi penurunan terhadap PAD. Terutama di daerah kabupaten Padang Pariaman, kabupaten Solok, kabupaten Lima Puluh Kota; kabupaten Agam, dan kabupaten Pasaman Barat yang mengalami penurunan PAD terendah. Akibatnya, kinerja keuangan pemerintah menjadi sangat rendah karena pemerintah kurang menggali sumber dan potensi daerah dengan baik. Fenomena yang diperoleh dari BPK RI perwakilan provinsi Sumatera Barat, bahwa sebagian besar kabupaten dan kota di Sumatera Barat masih memiliki PAD yang relatif kecil. Rata-rata masih berada dibawah sepuluh persen dari total APBD masing-masing Daerah. Sebagian besar kabupaten lainnya di Sumatera Barat memiliki PAD yang berkisar lima persen dan sepuluh persen PAD yang dimiliki oleh kota.

\section{REVIU LITERATUR DAN HIPOTESIS}

\section{Teori Keagenan (Agency Theory)}

Teori keagenan disebut sebagai hubungan atau kontrak antara principal dan agent (Siagian, 2011). Principal mempekerjakan agent untuk melakukan tugas demi kepentingan principal termasuk pendelegasian otorisasi pengambilan keputusan dari principal kepada agent. Menurut Halim dan Abdullah (2010) teori keagenan juga dapat diterapkan pada sektor publik. Kemudian dalam penelitian Ujiyantho dan Pramuka (2007) menyatakan bahwa hubungan keagenan muncul ketika satu atau lebih principal mempekerjakan agent untuk memberikan suatu jasa dan kemudian mendelegasikan wewenang pengambilan keputusan kepada agent tersebut. Berdasarkan hal tersebut seorang agent wajib untuk mempertanggungjawabkan mandat yang diberikan oleh principal kepadanya.

Dari definisi diatas dapat disimpulkan bahwa teori keagenan adalah gambaran suatu hubungan antara kedua belah pihak di mana salah satunya berperan sebagai pemberi wewenang sedangkan pihak lainnya berperan sebagai penerima yang bertugas untuk melaksanakan dan mempertanggungjawabkan kepentingan yang telah dilimpahkan.

\section{Kinerja Keuangan Pemerintah Daerah}

Kinerja Mahsun (2006) adalah gambaran mengenai tingkat pencapaian pengelolaan keuangan atas pelaksanaan suatu kegiatan program kebijakan dalam mewujudkan sasaran, tujuan, visi dan misi pemerintah daerah. Kinerja keuangan pemerintah daerah adalah hasil penilaian secara kuantitatif dari suatu kegiatan/program dalam mewujudkan sasaran dan tujuan pemerintah daerah. Penilaian kinerja keuangan pemerintah daerah digunakan sebagai bahan untuk mengevaluasi dan menentukan langkah-langkah yang akan dilakukan agar kualitas sektor publik jauh lebih baik. 


\section{Pendapatan Asli Daerah (PAD)}

Menurut Halim (2012) pendapatan asli daerah (PAD) adalah penerimaan yang diperoleh daerah dari sumber-sumber dalam wilayahnya sendiri yang dipungut berdasarkan perundangundangan yang berlaku. Menurut Peraturan Pemerintah Nomor 12 Tahun 2019 PAD terdiri dari pajak daerah, retribusi daerah, hasil pengelolaan kekayaan daerah yang dipisahkan dan lain-lain pendapatan asli daerah yang sah.

\section{Dana Alokasi Umum (DAU)}

Berdasarkan Peraturan Pemerintah Nomor 12 Tahun 2019 tentang pengelolaan keuangan daerah, dana alokasi umum (DAU) adalah dana yang bersumber dari pendapatan APBN yang dialokasikan dengan tujuan pemerataan kemampuan keuangan antar daerah untuk mendanai kebutuhan daerah dalam rangka pelaksanaan desentralisasi.

\section{Belanja Daerah}

Berdasarkan Peraturan Pemerintah Nomor 12 Tahun 2019 tentang pengelolaan keuangan daerah, belanja daerah adalah semua kewajiban pemerintah daerah yang diakui sebagai pengurang nilai kekayaan bersih dalam periode tahun anggaran berkenaan. Belanja daerah dialokasikan dengan memprioritaskan pendanaan urusan pemerintahan wajib terkait dengan pelayanan dasar dalam rangka pemenuhan standar pelayanan minimal. Adapun klasifikasi belanja daerah menurut Peraturan Pemerintah Nomor 12 Tahun 2019 terdiri dari belanja operasi, belanja modal, belanja tidak terduga dan belanja transfer.

\section{Pengembangan Hipotesis}

\section{Pendapatan Asli Daerah terhadap Kinerja Keuangan Pemerintah Daerah}

Pendapatan Asli Daerah merupakan sumber pendapatan yang paling penting bagi sebuah daerah dalam memenuhi kebutuhannya. Di samping itu, PAD berperan penting dalam menentukan kemampuan daerah dalam menyelenggarakan kegiatan pemerintahan dalam otonomi daerah. Otonomi daerah dan desentralisasi fiskal mengharapkan pemerintah daerah memiliki kemandirian yang lebih besar dalam keuangan daerah. Oleh sebab itu, peranan PAD sangat menentukan kinerja keuangan pemerintah daerah. Adanya sumber daya dan potensi yang dimiliki oleh masing-masing daerah diharapkan dapat dimanfaatkan untuk meningkatkan penerimaan daerah. Penerimaan daerah tersebut diperlukan untuk mendanai segala kewajiban daerah dalam menjalankan pemerintahannya, termasuk untuk digunakan dalam meningkatkan kesejahteraan masyarakat.

PAD yang dihasilkan daerah memiliki kontribusi penting terhadap pertumbuhan pendapatan sehingga pemerintah daerah mampu meminimalkan ketergantungannya terhadap pemerintah pusat. Pernyataan tersebut sejalan dengan penelitian yang dilakukan oleh Nugroho dan Rohman (2012) yang mengungkapkan bahwa tingginya penerimaan dari pendapatan asli daerah dapat meningkatkan kemandirian pemerintah daerah sehingga berdampak pada kinerja keuangan pemerintah daerah. Darwanis dan Saputra (2014) mengemukakan bahwa pemerintah bisa meningkatkan PAD dengan memungut retribusi dan pajak daerah sehingga bisa meningkatkan pertumbuhan kinerja keuangann pemerintah daerah. Berdasarkan teori dan hasil penelitian sebelumnya, maka hipotesis yang diajukan dalam penelitian ini adalah sebagai berikut:

H1: Pendapatan asli daerah berpengaruh positif terhadap kinerja keuangan pemerintah Daerah

\section{Dana Alokasi Umum terhadap Kinerja Keuangan Pemerintah Daerah.}

Dana Alokasi Umum merupakan salah satu dana yang berasal dari dana perimbangan. Julitawati (2012) menguji pengaruh DAU terhadap kinerja keuangan pemerintah 
kabupaten/kota di Provinsi Nanggroe Aceh Darussalam. Hasil penelitiannya menunjukkan bahwa DAU berpengaruh terhadap kinerja keuangan pemerintah kabupaten/kota di provinsi tersebut. Berdasarkan teori dan hasil penelitian sebelumnya, maka hipotesis yang diajukan dalam penelitian ini adalah sebagai berikut:

H2: Dana alokasi umum berpengaruh positif terhadap kinerja keuangan pemerintah daerah

\section{Belanja Daerah terhadap Kinerja Keuangan Pemerintah Daerah.}

Penelitian Ardya (2015) menunjukkan bahwa, belanja daerah berpengaruh positif terhadap kinerja keuangan pemerintah daerah. Hal tersebut sejalan dengan penelitian yang dilakukan oleh Reny (2016) menyatakan bahwa, belanja daerah merupakan faktor yang berpengaruh terhadap kinerja keuangan pemerintah daerah. Berdasarkan teori dan hasil penelitian sebelumnya, maka hipotesis yang diajukan dalam penelitian ini adalah sebagai berikut:

H3: Belanja Daerah berpengaruh positif terhadap Kinerja Keuangan Pemerintah Daerah.

\section{METODE PENELITIAN}

Jenis penelitian ini adalah penelitian kuantitatif karena penelitian ini banyak menggunakan angka dan analisis yang dilakukan menggunakan statistik. Populasi dalam penelitian ini adalah seluruh kabupaten/kota di Sumatera Barat yang berjumlah 19 kabupaten/kota. Penelitian ini menggunakan data laporan keuangan terbaru yaitu tahun 2015-2018. Objek penelitian ini adalah laporan realisasi APBD. Penelitian ini menggunakan data sekunder yaitu data yang telah diolah lebih lanjut dan disajikan oleh pihak lain. Data tersebut berupa laporan realisasi APBD kabupaten/kota di Provinsi Sumatera Barat tahun anggaran 2015-2018. Data bersumber dari publikasi Badan Pemeriksa Keuangan (BPK) Perwakilan Provinsi Sumatera Barat yaitu wesite resmi https://padang.bpk.go.id/.

\section{Variabel Penelitian}

Menurut Indriantoro dan Supomo (2014) variabel dependen adalah variabel yang menjelaskan atau dipengaruhi oleh variabel independen. Dalam penelitian ini variabel dependennya adalah Kinerja Keuangan Pemerintah Daerah (Y). Menurut Indriantoro dan Supomo (2014) variabel Independen adalah tipe variabel yang menjelaskan atau mempengaruhi variabel yang lain. Variabel ini disebut juga variabel yang diduga sebagai sebab variabel yang mendahului. Variabel independen yang digunakan pada penelitian ini adalah PAD $\left(\mathrm{X}_{1}\right)$, DAU $\left(\mathrm{X}_{2}\right)$, dan Belanja Daerah (X3).

\section{Pengukuran Variabel}

\section{Kinerja Keuangan Pemerintah Daerah}

Pengukuran variabel kinerja keuangan pemerintah daerah dapat diukur dengan perhitungan :

$$
\text { Rasio Efisiensi }=\frac{\text { Realisasi Pengeluaran }}{\text { Realisasi Penerimaan }} \times 100 \%
$$

\section{Variabel Pendapatan Asli Daerah (PAD)}

Pengukuran variabel PAD ini diukur dengan skala rasio. PAD dapat diukur dengan perhitungan :

$\mathrm{PAD}=$ Total pajak daerah + total retribusi daerah + total hasil pengelolaan kekayaan daerah yang dipisahkan + lain-lain pendapatan daerah yang sah.

Variabel Dana Alokasi Umum

DAU Kabupaten $/$ Kota $=90 \% \times 10 \%$ x PDN (Pendapatan Dalam Negeri) $\times$ Bobot DAU 


\section{Variabel Belanja Daerah}

Menurut Peraturan Pemerintah Nomor 12 Tahun 2019 belanja daerah terdiri dari; belanja operasi, belanja modal, belanja tidak terduga dan belanja transfer.

Belanja Daerah $=$ Total belanja operasi + total belanja modal + total belanja tidak terduga + Total belanja transfer

\section{Teknik Analisis Data}

\section{Analisis Statistik Deskriptif}

Menurut Sugiyono (2017) statistik deskriptif adalah statistik yang digunakan untuk menganalisis data dengan cara mendeskripsikan atau menggambarkan data yang telah terkumpul sebagaimana adanya tanpa bermaksud membuat kesimpulan yang berlaku untuk umum atau generalisasi. Teknik deskriptif dalam penelitian ini digunakan untuk menginterpretasikan nilai rata-rata, nilai maksimum, dan nilai minimum dari masing-masing variabel penelitian.

\section{Uji Asumsi Klasik}

Pengujian asumsi klasik ini bertujuan untuk melihat kelayakan model serta untuk mengetahui apakah terdapat pelanggaran asumsi klasik dalam model regresi berganda, karena model regresi yang baik adalah model yang lolos dari pengujian asumsi klasik. Terdapat empat asumsi dasar yang harus dipenuhi oleh model regresi agar parameter estimasi tidak bias yaitu uji normalitas, uji multikolinearitas, uji heteroskedastisitas, dan uji autokorelasi

\section{Analisis Regresi Linear Berganda}

Alat regresi berganda digunakan untuk melihat pengaruh beberapa variabel independen terhadap variabel dependen. Persamaan regresi untuk menguji hipotesis tersebut adalah sebagai berikut:

$$
\mathrm{Y}=\alpha+\beta_{1} \mathrm{X}_{1}+\beta_{2} \mathrm{X}_{2}+\beta_{3} \mathrm{X}_{3}+\varepsilon
$$

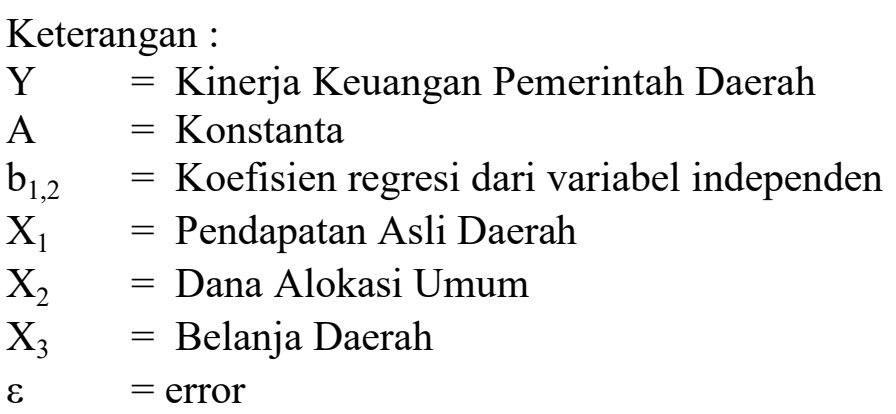

\section{HASIL DAN PEMBAHASAN \\ Statistik Deskriptif}

Statistik deskriptif digunakan untuk mempermudah dalam melihat gambaran mengenai variabel yang diteliti dan setelah melalui proses pengolahan dengan menggunakan program SPSS. Dari SPSS menunjukkan bahwa, nilai rata-rata kinerja keuangan daerah adalah 1,0041. Sedangkan nilai tertinggi dan nilai terendah kinerja keuangan daerah adalah 1,15 dan 0,90 .

Pada nilai rata-rata pendapatan asli daerah diperoleh angka sebesar Rp. 101.526.046.247,79 sedangkan, nilai Pendapatan Asli Daerah tertinggi dan terendah berada di angka Rp. 548.653.179.266 dan Rp. 29.680.784.157. Nilai rata-rata Dana Alokasi Umum 
adalah Rp. 599.060.870.077,95, sedangkan nilai terendah dan tertinggi sebesar Rp. 343.008.704.000 dan Rp. 1.120.046.168.000. Selanjutnya, pada Belanja Daerah nilai terendah dan tertinggi sebesar Rp. 477.740.630.854 dan Rp. 2.177.932.844.481 sedangkan nilai rata-rata Belanja Daerah sebesar Rp. 999.064.955.884,86.

\section{Analisis Regresi Linear Berganda}

Berdasarkan hasil output SPSS dapat dianalisis model regresi berganda sebagai berikut:

$$
\mathrm{Y}=1,046-2,718 \mathrm{X} 1-7,617 \mathrm{X} 2+4,421 \mathrm{X} 3
$$

Dari persamaan diatas dapat dijelaskan bahwa: Nilai konstanta sebesar 1,046 mengidentifikasikan bahwa jika signifikan variabel independen yaitu PAD, DAU dan Belanja Daerah adalah nol (konstan) maka kinerja keuangan. Koefisien PAD sebesar -2,718 mengidentifikasikan bahwa setiap peningkatan satu satuan PAD akan mengakibatkan penurunan pada kinerja keuangan. Koefisien DAU sebesar -7,617 mengidentifikasikan bahwa setiap penurunan satu satuan DAU akan mengakibatkan kenaikan pada kinerja keuangan. Koefisien Belanja Daerah sebesar 4,421 mengidentifikasikan bahwa setiap peningkatan satu satuan Belanja Daerah akan mengakibatkan penurunan kinerja keuangan.

\section{Pengujian Hipotesis}

Berdasarkan analisis hasil spss terlihat bahwa nilai sig $0,000<0,05$. Hal tersebut menggambarkan bahwa, pendapatan asli daerah (PAD), dana alokasi umum (DAU) dan belanja daerah secara bersama-sama berpengaruh terhadap tingkat kinerja keuangan pemerintah daerah kabupaten/kota di provinsi Sumatera Barat.

Hipotesis pertama dalam penelitian ini adalah pendapatan asli daerah berpengaruh positif terhadap kinerja keuangan pemerintah daerah. Dari tabel di atas menunjukkan bahwa, PAD memiliki nilai signifikansi sebesar $0,002<0,05$ artinya, PAD berpengaruh signifikan positif terhadap kinerja keuangan pemerintah daerah. Berdasarkan hasil pengujian tersebut dapat disimpulkan bahwa hipotesis 1 (H1) diterima.

Hipotesis kedua dalam penelitian ini adalah dana alokasi umum (DAU) berpengaruh positif terhadap kinerja keuangan pemerintah daerah. Dari tabel di atas menunjukkan bahwa, DAU memiliki nilai signifikansi sebesar $0,000<0,05$. Artinya DAU berpengaruh signifikan positif terhadap kinerja keuangan pemerintah daerah. Berdasarkan hasil pengujian tersebut dapat disimpulkan bahwa hipotesis $2(\mathrm{H} 2)$ diterima.

Hipotesis ketiga dalam penelitian ini adalah belanja daerah berpengaruh positif terhadap kinerja keuangan pemerintah daerah. Dari tabel diatas menunjukkan bahwa belanja daerah memiliki nilai signifikansi sebesar $0,000<0,05$. Artinya belanja daerah berpengaruh signifikan positif terhadap kinerja keuangan pemerintah daerah. Berdasarkan hasil pengujian tersebut dapat disimpulkan bahwa hipotesis 3 (H3) diterima.

\section{Uji Koefisien Determinasi $\left(\mathbf{R}^{2}\right)$}

Adjusted $R$ Square sebesar 0,274 hal ini menunjukkan bahwa PAD, DAU dan belanja daerah berpengaruh terhadap kinerja keuangan daerah sebesar 27,4\% sedangkan 72,6\% dipengaruhi oleh faktor lain yang tidak terdeteksi dalam penelitian ini.

\section{Pembahasan}

\section{Pengaruh PAD terhadap Kinerja Keuangan Pemerintah Daerah}

Berdasarkan hasil penelitian pada tabe16 menunjukkan bahwa tingkat signifikansi terhadap pendapatan asli daerah sebesar $0,002<0,05$. Hal tersebut dapat disimpulkan bahwa, pendapatan asli daerah berpengaruh signifikan terhadap kinerja keuangan pemerintah daerah. Hasil pengujian ini sesuai dengan teori dan hipotesis sebelumnya yang menyatakan bahwa 
Pendapatan Asli Daerah berpengaruh signifikan positif terhadap kinerja keuangan pemerintah daerah. PAD yang dihasilkan daerah memiliki kontribusi penting dalam meningkatkan kinerja keuangan pemerintah daerah.

Pernyataan diatas sejalan dengan penelitian yang dilakukan oleh Nugroho dan Rohman (2012) yang mengungkapkan bahwa, tingginya penerimaan pendapatan asli daerah dapat meningkatkan kemandirian pemerintah daerah sehingga hal tersebut berimplikasi pada kinerja keuangan pemerintah daerah. Darwanis dan Saputra (2014) mengemukakan bahwa pemerintah daerah dapat meningkatkan pendapatan asli daerah melalui pungutan yang bersumber dari pajak daerah dan retribusi daerah sehingga pemerintah daerah meningkatkan pertumbuhan kinerja keuangannya. Hasil penelitian yang dilakukan oleh Yuliasti dkk (2018) juga menunjukkan bahwa pendapatan asli dDaerah berpengaruh positif dan signifikan terhadap kinerja keuangan pemerintah daerah.

\section{Pengaruh DAU Terhadap Kinerja Keuangan Pemerintah Daerah}

Hasil penelitian ini menunjukkan bahwa dana alokasi umum (DAU) berpengaruh positif terhadap kinerja keuangan pemerintah daerah. Hasil SPSS menunjukkan bahwa DAU memiliki nilai signifikansi sebesar $0,000<0,05$. Artinya DAU berpengaruh signifikan positif terhadap kinerja keuangan pemerintah daerah. Hasil pengujian tersebut sesuai dengan teori dan hipotesis sebelumnya yang menyatakan bahwa dana alokasi umum berpengaruh signifikan positif terhadap kinerja keuangan pemerintah daerah.

Pernyataan diatas sejalan dengan penelitian yang dilakukan oleh Julitawati (2012) yang menguji pengaruh DAU sebagai bagian dari dana perimbangan terhadap kinerja keuangan pemerintah kabupaten/kota di provinsi Nanggroe Aceh Darussalam. Hasil penelitiannya menunjukkan bahwa DAU berpengaruh signifikan positif terhadap kinerja keuangan pemerintah kabupaten/kota di provinsi tersebut. Hasil penelitian yang dilakukan oleh Rukmana (2013) membuktikan bahwa DAU berpengaruh signifikan positif terhadap kinerja keuangan pemerintah daerah. Pernyataan tersebut sejalan dengan penelitian yang dilakukan oleh Refi dkk (2018) yang menyatakan bahwa dana alokasi umum berpengaruh signifikan terhadap kinerja keuangan pemerintah pada kabupaten/kota di Provinsi Kepulauan Riau periode 2011-2016.

\section{Pengaruh Belanja Daerah Terhadap Kinerja Keuangan Pemerintah Daerah}

Dalam penelitian ini adalah belanja daerah berpengaruh positif terhadap kinerja keuangan pemerintah daerah. Hasil SPSS menunjukkan bahwa belanja daerah memiliki nilai signifikansi sebesar $0,000<0,05$. Artinya belanja daerah berpengaruh signifikan positif terhadap kinerja keuangan pemerintah daerah. Koefisien dari belanja daerah juga menunjukkan angka sebesar 4,421 hal tersebut mengidentifikasikan bahwa setiap peningkatan satu satuan belanja daerah akan mengakibatkan penurunan kinerja keuangan sebesar 4,421. Hasil pengujian tersebut sesuai dengan teori dan hipotesis sebelumnya yang menyatakan bahwa belanja daerah berpengaruh signifikan positif terhadap kinerja keuangan pemerintah daerah. Pernyataan tersebut juga didukung oleh penelitian yang dilakukan Ardya (2015) menunjukkan bahwa, belanja daerah berpengaruh positif terhadap kinerja keuangan pemerintah daerah. Hal tersebut sejalan dengan penelitian yang dilakukan oleh Reny (2016) yang menyatakan bahwa, belanja daerah merupakan faktor yang berpengaruh positif terhadap kinerja keuangan pemerintah daerah.

\section{SIMPULAN, KETERBATASAN, DAN SARAN Simpulan}

Penelitian ini bertujuan untuk melihat seberapa besar pengaruh pendapatan asli daerah (PAD), dana alokasi umum (DAU), dan belanja daerah terhadap kinerja keuangan 
pemerintah daerah pada kabupaten/kota di provinsi Sumatera Barat tahun 2015-2018. Berdasarkan hasil penelitian dan pengujian pada hipotesis yang telah dilakukan terdapat tiga kesimpulan sebagai berikut.

Pertama, pendapatan asli daerah berpengaruh signifikan positif terhadap kinerja keuangan pemerintah daerah. Hasil pengujian PAD ini sesuai dengan teori dan hipotesis sebelumnya yang menyatakan bahwa pendapatan asli daerah berpengaruh signifikan positif terhadap kinerja keuangan pemerintah daerah. Kedua, hasil penelitian ini menunjukkan bahwa dana alokasi umum (DAU) berpengaruh positif terhadap kinerja keuangan pemerintah daerah. Hasil pengujian tersebut sesuai dengan teori dan hipotesis sebelumnya yang menyatakan bahwa dana alokasi umum berpengaruh signifikan positif terhadap kinerja keuangan pemerintah daerah. Ketiga, hasil pengujian pada belanja daerah adalah belanja daerah berpengaruh positif terhadap kinerja keuangan pemerintah daerah. Hasil pengujian tersebut sesuai dengan teori dan hipotesis sebelumnya yang menyatakan bahwa belanja daerah berpengaruh signifikan positif terhadap kinerja keuangan pemerintah daerah.

\section{Saran}

Berdasarkan hasil penelitian yang telah dilakukan, maka peneliti menyarankan untuk penelitian selanjutnya agar memperluas periode pengamatan agar lebih maksimal dalam membandingkan hasil penelitian dari tahun ke tahun. Untuk peneliti selanjutnya, sebaiknya menambah variabel lain dalam penelitian karena, selain Pendapatan Asli Daerah, Dana Alokasi Umum dan Belanja Daerah yang telah digunakan dalam penelitian ini, masih terdapat beberapa variabel lain yang bisa ditambahkan.

\section{DAFTAR PUSTAKA}

Abdullah, A., Dri, A. S., \& Febriansyah, F. Pengaruh Pendapatan Asli Daerah, Dana Alokasi Umum, dan Alokasi Khusus Terhadap Kinerja Keuangan Pemerintah Daerah Kabupaten/Kota se-Sumatera Bagian Selatan. Jurnal Akuntansi, 3(1), 41-67.

Andirfa, M., Basri, H., \& Majid, M. S. A. (2016). Pengaruh belanja modal, dana perimbangan dan pendapatan asli daerah terhadap kinerja keuangan kabupaten dan kota di Provinsi Aceh. Jurnal Administrasi Akuntansi: Program Pascasarjana Unsyiah, 5(3).

Antari, N. P. G. S., \& Sedana, I. B. P. (2018). Pengaruh Pendapatan Asli Daerah dan Belanja Modal Terhadap Kinerja Keuangan Pemerintah Daerah. E-Jurnal Manajemen Universitas Udayana, 7(2).

Apridiyanti, A. (2019). Pengaruh pendapatan asli daerah terhadap kinerja keuangan pemerintah daerah Kabupaten dan Kota di Jawa Barat 2013-2017. JAE (JURNAL AKUNTANSI DAN EKONOMI), 4(3), 32-41.

Armaja, A., Ibrahim, R., \& Aliamin, A. (2017). Pengaruh Kekayaan Daerah, Dana Perimbangan Dan Belanja Daerah Terhadap Kinerja Keuangan (Studi pada Kabupaten/Kota di Aceh). Jurnal Perspektif Ekonomi Darussalam, 3(2), 168-181.

BPS. (2016). Pedoman Pencacahan Survei Statistik Keuangan Daerah 2016. Jakarta: BPS.

BPS. (2017). Statistik Keuangan Pemerintah Daerah Provinsi dan Kabupaten/Kota Sumatera Barat 2015-2016. Padang: BPS.

Darwanis, D., \& Saputra, R. (2014). Pengaruh Belanja Modal terhadap Pendapatan Asli Daerah dan Dampaknya Pada Kinerja Keuangan Pemerintah Daerah (Studi Empiris Pada Pemerintah Daerah Kabupaten/Kota Di Provinsi Aceh). Jurnal Dinamika Akuntansi dan Bisnis, 1(2), 183-199.

Erlina, O. S. Rambe, dan Rasdianto. (2015). Akuntansi Keuangan Daerah Berbasis Akrual. Penerbit Salemba Empat, Jakarta. 
Fahmi, I. (2012). Analisis Kinerja Keuangan. Bandung: Alfabeta, 3.

Garini, A. (2015). Pengaruh belanja daerah, temuan audit dan size terhadap kinerja keuangan pemerintah daerah (studi empiris pada pemerintah daerah kabupaten/kota di Indonesia) (Doctoral dissertation, UNNES).

Halim, A. (2007). Akuntansi Sektor Publik: Pengelolaan Keuangan Daerah Edisi Ketiga. Jakarta: Erlangga.

Halim, A. (2012). Akuntansi Sektor Publik: Akuntansi Keuangan Daerah. Edisi 4, Penerbit Salemba Empat.

Halim, A., \& Abdullah, S. (2010). Hubungan dan Masalah Keagenan di Pemerintah Daerah. Jurnal Akuntansi Pemerintah, 2(1), 53-64.

http://bpkad.banjarkab.go.id/index.php/2017/09/07/kinerja-keuangan-daerah/

https://padang.bpk.go.id/

Indriantoro, Nur dan Supomo, Bambang. (2014). Metodologi Penelitian Bisnis. Yogyakarta: BPFE- Yogyakarta.

Julitawati, E. Darwanis, dan Jalaluddin, (2012). Pengaruh Pendapatan Asli Daerah (PAD) dan Dana Perimbangan terhadap Kinerja Keuangan Pemerintah Kabupaten/Kota di Provinsi Aceh. Jurnal Akuntansi Universitas Syiah Kuala, 1, 15-29.

Leki, Y., Naukoko, A. T., \& Sumual, J. I. (2018). Pengaruh Pendapatan Asli Daerah dan Belanja Modal terhadap Kinerja Keuangan pada Pemerintah Kabupaten Halmahera Barat. Jurnal Berkala Ilmiah Efisiensi, 18(5).

Mahmudi. (2010). Manajemen Kinerja Sektor Publik (Edisi kedua). Yogyakarta: UPP STIM YKPN.

Mahmudi. (2016.) Analisis Laporan Keuangan Pemerintah Daerah. Yogyakarta: UPP STIM YKPN.

Mahsun, M. (2006). Pengukuran Kinerja Sektor Publik. Yogyakarta: BPFE.

Mardiasmo. (2012). Akuntansi Sektor Publik. Yogyakarta : ANDI.

Nugroho, F., \& Rohman, A. (2012). Pengaruh Belanja Modal Terhadap Pertumbuhan Kinerja Keuangan Daerah Dengan Pendapatan Asli Daerah Sebagai Variabel Intervening (Studi Kasus Di Propinsi Jawa Tengah) (Doctoral dissertation, Fakultas Ekonomika dan Bisnis).

Indonesia, R. (2004). Undang-Undang Republik Indonesia Nomor 33 tahun 2004 Tentang Perimbangan Keuangan antara Pemerintah Pusat dan Pemerintah Daerah.

Indonesia, R. (2006). Peraturan Menteri Dalam Negeri No. 13 Tahun 2006 Tentang Pedoman Pengelolaan Keuangan Daerah.

Indonesia, R. (2009). Peraturan Menteri Dalam Negeri Nomor 25 Tahun 2009 Tentang Pedoman Penyusunan Anggaran Pendapatan Dan Belanja Daerah Tahun Anggaran 2010.

Indonesia, R. (2014). Undang-Undang Nomor 23 Tahun 2014 Tentang Pemerintah Daerah.

Indonesia, R. (2019). Peraturan Pemerintah Nomor 12 Tahun 2019 Tentang Pengelolaan Keuangan Daerah.

Rukmana, W. V. (2013). Pengaruh Pajak Daerah, Retribusi Daerah dan Dana Perimbangan Terhadap Kinerja Keuangan Pemerintah Provinsi Kepulauan Riau. Skripsi. Universitas Maritim Raja Ali Haji Tanjung Pinang.

Retnowati, R. (2016). Analisis Pengaruh Tingkat Kekayaan Daerah, Belanja Daerah, Ukuran Pemerintah Daerah, Leverage Dan Intergovernmental Revenue Terhadap Kinerja Keuangan Pemerintah Daerah (Studi Empiris Pada Pemerintah Daerah/Kota Se-Jawa Tengah 2011-2013) (Doctoral dissertation, Universitas Muhammadiyah Surakarta).

Siagian, S. (2011). Manajemen Sumber Daya Manusia. Jakarta: PT. Bumi Aksara

Sugiyono (2017). Metode Penelitian Kombinasi (Mixed Methods). Bandung: Alfabeta. 
Sumarjo, H. (2010). Pengaruh Karakteristik Pemerintah Daerah terhadap Kinerja Keuangan Pemerintah Daerah.

Susanti, R., \& Ratih, A. E. (2018). Pengaruh Pendapatan Asli Daerah, Dana Alokasi Umum, Dana Alokasi Khusus, Dan Belanja Modal, Terhadap Kinerja Keuangan Pada Pemerintah Kabupaten/Kota Diprovinsi Kepulauan Riau Periode 2011-2016. Jurnal Revi. Tanjungpinang: Program Sarjana Fakultas Ekonomi dan Bisnis Universitas Maritim Raja Ali Haji(UMRAH).

Ujiyantho, M. A., \& Pramuka, B. A. (2007). Mekanisme Corporate Governance, Manajemen Laba dan Kinerja Keuangan. Simposium Nasional Akuntansi X, 10(6), 1-26. 